Abstracta Iranica Abstracta Iranica

Revue bibliographique pour le domaine irano-aryen

Volume 29 | 2008

Comptes rendus des publications de 2006

\title{
Neqāb-e naqd. Tehrān, Našr-e Češme, 1383/2004 ou 2005, 334 p. [Le masque de la critique]
}

\section{Poupak Rafii Nejad}

\section{(2) OpenEdition}

1 Journals

\section{Édition électronique}

URL : http://journals.openedition.org/abstractairanica/31842

DOI : 10.4000/abstractairanica.31842

ISSN : 1961-960X

\section{Éditeur :}

CNRS (UMR 7528 Mondes iraniens et indiens), Éditions de l'IFRI

\section{Édition imprimée}

Date de publication : 15 mai 2008

ISSN : 0240-8910

\section{Référence électronique}

Poupak Rafii Nejad, « Neqāb-e naqd. Tehrān, Našr-e Češme, 1383/2004 ou 2005, 334 p. [Le masque de la critique] », Abstracta Iranica [En ligne], Volume 29 | 2008, document 349, mis en ligne le 15 septembre 2008, consulté le 26 septembre 2020. URL : http://journals.openedition.org/ abstractairanica/31842 ; DOI : https://doi.org/10.4000/abstractairanica.31842

Ce document a été généré automatiquement le 26 septembre 2020

Tous droits réservés 


\title{
Neqāb-e naqd. Tehrān, Našr-e Češme, $1383 / 2004$ ou 2005,334 p. [Le masque de la critique]
}

\author{
Poupak Rafii Nejad
}

1 Tondrow Șāleh tente de dresser un état des lieux de la critique littéraire par une série d'entretiens avec quelques écrivains et spécialistes de la littérature persane. Dès son introduction, il déplore le manque d'interlocuteurs et l'inadéquation de l'appareil critique à la littérature contemporaine, qu'il considère comme stagnante et stérile. Les questions posées par T.S. à ses interlocuteurs sont variées, même si elles cherchent toujours à ouvrir des pistes pour la compréhension de l'état actuel de la littérature persane.

Les interlocuteurs de T.S. pour ces entretiens sont Christophe Balaÿ : « à propos de la littérature (roman et nouvelle) contemporaine d'Iran », pp. 19-55 ; 'Enāyat Samī‘ī (critique littéraire, poète) : "Rupture intelligible dans la raison critique iranienne ", pp. 57-92 ; Morād Farhādpūr (traducteur, critique) : « Notre problème est notre manque de maturité historique ", pp. 93-123 ; Medīā Kāšīgar (poète, romancier et traducteur) : «La critique littéraire dans la société et la littérature opaque », pp. 125-192 ; Mas'ūd Kowțarī (écrivain) : « Sociologie de la littérature et critique sociologique », pp. 193-235 ; Ḥoseyn Mīr 'Ābedīnī (critique littéraire) : " La critique littéraire dans le jeu sociopolitique», pp. 237-271 ; Sīmā Vazīrniyā (écrivain, critique) : " La critique psychanalytique et la littérature actuelle d'Iran ", pp. 273-305 ; Șadīqe Vasmaqī (poétesse, traductrice) : «L'écrivain dans les filets de la politique », pp. 307-326.

Qui voile, qui dévoile ? Qui masque, qui démasque ? Neqāb-e naqd [Le masque de la critique] s'efforce de répondre à ces questions. 
INDEX

Thèmes: 11.1.2. Littérature persane moderne

\section{AUTEURS}

POUPAK RAFII NEJAD

CNRS - Mondes iranien et indien - Paris 